\title{
Specification a model for study of biopolitics
}

Cruz Garcia Lirios ${ }^{1}$.

1 - Universidad Autónoma del Estado de México, México.

\begin{abstract}
Social work focused on intervention has generated models ranging from charity to the establishment of devices as public and social policies have crystallized in exclusion processes such as social issues, social domination, social suffering, loss the social bond and streamlining other. Discuss the scope and limits of social work as a device address to the management policies of the - Tecnopolitic - communication and management of - Necropolitic - emotions. Documental study with a selection of sources considering the keywords of exclusion, domination, suffering, tie and rationalization. Social Work as a device intervention should consider forms of state and government schemes to establish the scope and limits of social protection and social promotion. Social Work as interventional device could be oriented to the intercession, since in the framework of governance is necessary dialogue rather than imposition.
\end{abstract}

Keywords: Social Work; Device; Intervention; Domination; Biopolítica. 


\section{Introduction}

The aim of this paper is to discuss the scope and limits of social work as a preventive and thanatological device to the politics of fear, nepotism and known as biopolitics, necropolitics technopolitics and death. For this purpose, the basic concepts proposed by Michel Foucault and Alfredo Juan Manuel Carballeda exposed. Then, the categories of social fact, social issue, rationalization of another device, social suffering, social ties, social protection, social promotion and intervention with regard to the politics of fear, nepotism and death in order to discuss establish areas of opportunity of Social Work. Finally, a model for social diagnosis of biopolitics, the technopolitics and necropolitics specified.

Accordingly, work will establish the concept of device as a central axis in the discussion about the social work and occupational practice with an impact on local development; promoting autonomy, equity and shared responsibility.

\section{Biopolític, Necropolític and Tecnopolitic}

This section describes the basic concepts of the politics of fear, nepotism and instrumented as government actions to reduce conflict and social change death exposed.

The term refers to a rational Biopolítica administration and institutional practices for social control, reducing - conflicts. Anger, anxiety, distrust, indefention - based on obedience and conformity and the anticipation of social change (Tarazona, 2015, p.11). In this sense, it is a device because it connotes a civilized evolution based on resources and capabilities guided by a system of power crystallized status, money, origin, authority or force (Tarazona, 2015, p.13).

From both distinctions, it is possible to note that the concept of biopolitics refers to a forged industrial revolution and until then permanent device as to the reproduction of social domination refers (Bourdieu, 1999, p.14). 
However, the term Biopolítica fragmented and resulted necropolitics or administration of death make gradually die stress, helplessness, fear, terror or work - and technopolitics or communication management — adherents or deter dissidents — . Both dimensions, necropolitics and technopolitics not only show a management opportunities and social skills, but also two sophisticated devices through Information Technology and Communication (ICT) spread fear to legitimize the guidance of the State on public security; latent privacy and identity theft.

Biopolitics, Necropolitics and Technopolicy are control devices, fear and communication that legitimize domination, suffering and despair as civil society is organized in areas and networks to address these policies, generating devices that counteract the effects of policies social control, focusing on conflict and social change.

Social work, from its inception was a sectoral response to the injustices of colonization (Carballeda, 2103, p.18). It is a discipline that has evolved as the asymmetries between rulers and ruled are intensified because of Biopolitics, necropolitics and technopolitics. A review of the history of Social Work and its evolution in device emancipation and vindication allow you to appreciate their contribution general science and social sciences and the health sciences.

\section{Social work as intervention device}

Since its origins, its reconceptualization and contemporary stage Social Work has gone from welfare to question their social relevance as a device no longer playing for exclusion, but as prevention device and thanatological orientation (David et al., 2011). In this regard, it is important to discuss some current concepts such as; 1) Social fact; 2) Social question; 3) Rationalizing the other; 4) Social domination; 5) Social suffering; 6) Social bond; 7) Social protection and 8) Social promotion.

The concept of social fact is widely discussed by Durkheim (2001) to establish the object of study of sociology saw it as a product of common life (p.47), but in Social Work has been assumed as "a behavior or an idea which is present in a social group, accepted or not, through complex historical transmissions"(Carballeda, 2013, p.44). 
Ie, a social fact, from the perspective of Social Work, refers to a process of legitimation of the differences between rulers and ruled. In this sense, biopolitics is a social fact, since in both device power, has become increasingly sophisticated in necropolitics and technopolitics as governments and civil society have generated disagreements.

Regarding social issue, this refers to the identification of problem inherent in a social context (David et al, 2011, p.77); linked to public policies and affecting violated, marginalized or excluded sectors (Gómez, 2015, p.296). In this sense, biopolitics and dimensions of Necropolitics and Technopolicy are a social issue for its effects not only in society, but because being an instrument of power and reproduction of exclusion, are a permanent system that favors makers decisions to the detriment of those who must abide.

It is possible to observe that fact social issue social and allude to a control device, and sophisticated manipulation as asymmetries between political and civil actors were accentuated.

Streamlining the other is "the replacement of intimate submission to the usual (..) for planned adaptation to an objective situation of interest." (Weber, 2002, p.24). This is an internalization of the other as a subject of interest, either in terms of exclusion (Biopolitics), death (Necropolitics) or communication (Technopolicy). This is because the historical dominance device would be indicated by streamlining the other as a result of the implementation of policies that inhibit cooperation but exacerbate competition and exclusion.

On the concept of device, coined by Foucault (2003) it alludes to that "locate and select (..) to ensure the domain" (p.132). Or, "that coerces by look, an apparatus in which the techniques to see induce effects of power and where rejection, the means of coercion clearly seen those on whom they apply." (p. 158). Indeed, the device is the implementation of Biopolitics, while it seeks to control and management of sympathizers and supporters, but especially the conformity and obedience of dissidents and critics. 
Accordingly, the Social Work as a device would have a double connotation. The first refers to is part of the power and instrumented government action, reflected in the care and social services, but another part refers to the crystallization of initiatives of civil society organizations in areas or knowledge networks that promote to anticipate social issues or social fact and prevent spreading civil initiatives in order to be a device of the violated sectors, marginalized or excluded.

Thus, social domination "resides in the school or the state (...) places imposition of principles that are practiced within the most private of universes." (Bourdieu, 1999, p.15). Or, the social domination is a lynchpin of the devices state that embodies the patriarchy.

In the case of social suffering, it refers to poverty, indifference and ignorance (Malagon, 2012, p.207). Meanwhile indicator of social domination, the three sufferings appeal to a country devastated by the differences between political and social actors around, even alludes to a double exclusion is deprivation of social welfare by the state and loss of sense of community by the own group of belonging.

Indeed, the social suffering indicates the loss of social ties, either by poverty, indifference or ignorance, or by despair and indolence. In this process, the social bond "integration element subject to all corporate and key component of the amalgamation of society." (Carballeda, 2013, p.47). The loss of social ties involves the effectiveness of social domination crystallized into despair.

To social exclusion, indicated by the social fact, social issues, rationalization of other social domination and social suffering and loss of social ties, social work has developed an interventional device consisting of protection social — To prevent, reduce and address risks that produce social inequalities - , bearing in mind their vulnerability disappearance subjects of intervention "(Carballeda, 2013, p.63).

Thus, social protection as an indicator of the effectiveness of the intervention device is linked to social promotion - recipients to leave the place of rights risk and improve their social integration capabilities within collective projects -" (Carballeda, 2013, p.64). 
Therefore, the Social Work as interventional device to the effects of Biopolitics — Necropolític and Tecnopolític - aims to study the genealogy of social facts to reveal the social question, by systematizing cases of rationalization of other social domination, social suffering, social ties, social protection and social promotion.

In short, the Social Work as interventional device -protection and promotion of basic rights and needs of vulnerable groups such marginalized or excluded of human development would impact on the social question by establishing the central themes for discussion (scenario 1). Reduce social domination through dissemination of equity (hypothesis 2). Dismemberment of social suffering by way of a life free of violence (hypothesis 2.2), would encourage the social bond with openness to diversity of groups and their relationships (hypothesis 1.2) and finally, modify streamlining the other to promote their individual capacities, but above all collaborative (hypothesis $1.1,1.2 .1,2.1,2.2 .1$ ).

\section{Discussion}

The contribution of this document to social work lies in the systematization of hypotheses concerning a diagnostic device, intervention and evaluation. This is because the history of social work that goes charitable device consolidation evidence a process of exclusion or social fact would be indicated for 1) The social question, 2) Social domination, 3) Social suffering, 4) Loss of social ties and 5) The rationalization of the other. Each of these phases has been countered with the protection and promotion of fundamental social rights and forms of basic living free from violence.

However, being a device subject to public intervention and social policies - Biopolitics, increasingly frequent and preponderant in Latin America Necropolitics and Technopolicy —, then it is essential a historical review of the forms of government and regimes of State with the intention of establishing the political system according to the social Work as interventional device in the process of social exclusion. 
Under the violated, marginalized and excluded sectors are those most impacts the process of social exclusion, it is necessary to intervene according to local history the power of rulers or caciques. In this sense, the interventional device would be subject to the availability of community resources and capabilities of native groups such as migrants in the context or niche study, intervention and evaluation.

Therefore, a pending subject of Social Work as interventional device will be the articulation with public and social policies in relation to the excluded, marginalized or violated their most basic rights and guarantees groups.

\section{Conclusion}

Social work as a device address to the Biopolitics — Technopolicy and necropolitics — is a social process of social exclusion A matter, social domination, social suffering, social bond and rationalization of the other — that could be countered with the promotion of fundamental rights —, as the implementation of policies aimed at social protection and not the administration of communication and emotions of civil society.

\section{References}

Bourdieu, P. (1999). The male domination. Barcelona: Anagram.

Carballeda, A. (2013). The intervention in the social as a process. A methodological approach. Buenos Aires. Area.

David, N., Guevara, N., Rubio, J., Fernández, C. and Sierra, J. (2011). Social Work in Latin America: historical Approximations. Public Square, 4 (5), 72-97.

Durkheim, E. (2001). The rules of the method. Mexico: FCE.

Foucault, M. (2003). Discipline and Punish. Buenos Aires: Siglo XXI.

Gómez, S. (2015). The social question and its articulation with social work. Tabula Rasa. 22, 285-305.

Malagon, E. (2012). Foundations of Social Work. Bogotá: National University of Colombia. 
Tarazona, E. (2015). Biopolitics, technopolitics and necropolitics. Cohesion in power strategies or integrated governmental rationality in the era of capitalism terminal. Wandering Litoriales, 12 (4), 1175.

Weber, M. (2002). Economy and Society Mexico.. FCE. 